\title{
Size matters - Analysis of shell repair scars in endocerid cephalopods
}

\author{
Björn Kröger
}

Museum für Naturkunde, Leibniz-Institut für Evolutions- und Biodiversitätsforschung an der Humboldt-Universität zu Berlin, 10115 Berlin, Germany; e-mail: bjoekroe@gmx.de

$\begin{array}{ll} & \text { Abstract } \\ \begin{array}{l}\text { Received 16 September 2010 } \\ \text { Accepted 21 January 2011 } \\ \text { Published } 3 \text { August 2011 }\end{array} & \begin{array}{l}\text { Nearly one third of all conchs of Anthoceras buchi (Lesnikowa, 1949) from Baltoscan- } \\ \text { dia display healed apertural breakages. Often multiple of these repair scars can be } \\ \text { found in single conchs. Most of the scars are less than } 2 \text { mm deep, but deeper slit-like } \\ \text { repaired breakages occasionally occur. Small injuries are usually around the entire aper- } \\ \text { tural circumference, but the larger scars are concentrated at the ventral side of the } \\ \text { conch, which is interpreted as result of a protection from a hood. The adult diameter } \\ \text { of Anthoceras buchi is }>40 \text { mm. Conch regions that exceed } 30 \text { mm in diameter rarely }\end{array} \\ \text { contain evidence of multiple repair scars. The relative frequency of deep healed } \\ \text { bey Words }\end{array}$

\section{Introduction}

Endocerids are the dominant cephalopod group in the lower-middle Darriwilian limestones in Baltoscandia which historically were named "Vaginatum Limestone" ("Vaginatenkalk", Schmidt 1858). These limestones range from south-eastern Sweden to the St. Petersburg region, Russia, and are today subsumed under the Kunda Regional Stage limestones in Estonia, the Lynna, Obukhovo, and Simonkovo formations in the St. Petersburg region (Ivantsov 2003), and the Formation D in Öland, Sweden (Stouge 2004). Boulders of these formations are common in Northern Germany and northern Poland in the Pleistocene erratics, here the older stratigraphic terms "Lower Grey Orthoceratite Limestone" and "Lower Red Orthoceratite Limestone" are still in use by private fossil collectors.

The predominant endocerids in these limestones are the name giving straight, irregularly annulated longicones, that were subsumed under Anthoceras vaginatum (Schlotheim, 1820) by earlier authors. The conch of these endocerids is characteristically ornamented with prominent transverse striae. Five or more striae occur between two ribs. The largest specimens known meas- ure nearly $50 \mathrm{~mm}$ in diameter. Adult size was usually reached at diameters exceeding $40 \mathrm{~mm}$ (indicated by septal crowding). A considerable variation in conch ornamentation occurs between different specimens. In some specimens the transverse striae appear more irregularly spaced, while in others, they are very regularly spaced. The amplitude of the annulation varies between different specimens and in some specimens irregularly spaced constrictions occur on the steinkerns (Fig. 1). These cephalopods exceptionally often preserve traces of shell breakage and repair. Nearly a third of all conchs (29\%) in the collection of the Naturhistoriska Riksmuseet, Stockholm, Sweden, have traces of healed breakages.

Traces of failed predation are reported from other Ordovician mollusks (gastropods, monoplacophorans and tergomyans: Ebbestad \& Peel 1997; Ebbestad 1998; Isakar \& Ebbestad 2000; Alexander \& Dietl 2003; Lindström \& Peel 2005; Frisk \& Ebbestad 2007; Ebbestad \& Stott 2008). The shell repair frequencies documented in these reports range from 5-36\%. Ebbestad \& Stott (2008) demonstrated that differences in shell repair frequency can vary strongly between gastropod species in coeval rock samples. The authors inter- 


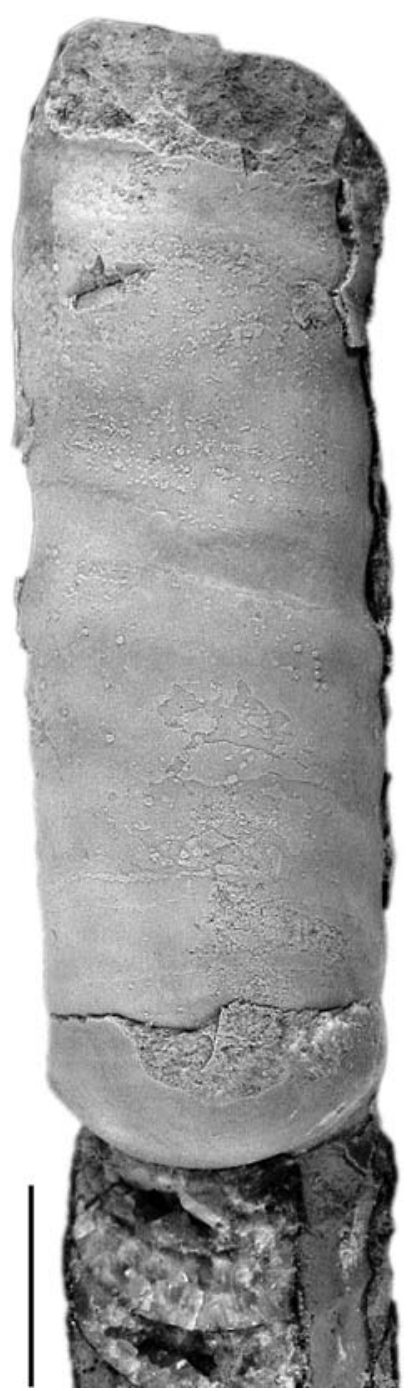

Figure 1. Complete body chamber steinkern and part of the phragmocone of Anthoceras buchi (Lesnikowa, 1949), TUG TUG 1309-1, from Kadaka railroad trench, Tallinn, Estonia (59.23.888N, 024.38.657E), Kunda Limestone, Middle Ordovician. The slightly oblique constriction of the body chamber is a result of an internal shell thickening. These shell thickenings occur at irregular distances in Anthoceras buchi. They are parallel to the peristome and are interpreted here as antipredatory traits. Scale bar $10 \mathrm{~mm}$.

preted the different injury frequency as a result of interspecific differences in predation intensity and emphasize the need for more detailed analyses in the background of the emerging complex (Ordovician) shell repair frequency pattern.

Leighton (2002) demonstrated that shell repair frequencies themselves are a poor predictor to predation intensity. Quantification of repair frequencies in individual size classes of injured conchs and of frequencies of multiple injuries in individual conchs is necessary to infer predation intensity (see also Ebbestad \& Stott 2008).

Here, I counted the repair scars in the Middle Ordovician endocerids of Anthoceras buchi (Lesnikova, $1949)$, = A. vaginatum, measured their size and position, and photographed the most spectacular injuries among them. The position, size, and shape of the repair scars potentially provide information of predator-prey interactions, on the shape of the endocerid soft body anatomy, the lifestyle, and the causes of some evolutionary trends of these common cephalopods.

The description and analysis of Anthoceras buchi required a short review of this common annulated endocerid, which is better known by its older, but invalid, name "Endoceras vaginatum".

Finally, I included in this analysis the description and illustration of an exceptionally preserved specimen of Anthoceras buchi which revealed the original colour pattern of this species.

\section{Material}

The Naturhistoriska Riksmuseet Stockholm (NRM) has a collection of about 236 specimens of these endocerids from Öland, Västergotland, Dalarna, and Östergotland. The specimens are conch fragments of different diameter, usually with a length of $50-150 \mathrm{~mm}$. Only in a few cases the conch fragments are more complete. The analysis of the material at the NRM was completed with single specimens from Harku near Tallinn, Estonia, which are in the collection of the Tartu Ülikool Geoloogia Muuseum (TUG), and from boulders of Pleistocene erratics of northern Germany which are in the collection of the Naturkunde Museum Berlin (MB).

\section{Taxonomic remarks}

The list of endocerids assigned to Orthoceratites vaginatum Schlotheim, 1820 is very long. Originally the name was given as a nomen nudum to specimens of probably Jurassic age from the Swabian Alb in Germany by Schlotheim (1813). Schlotheim (1820, p. 5354) described annulated and transversely striated longicones from Reval (Tallinn), Estonia as O. vaginatus, and refers to the figures in Knorr \& Walch (17681774, Volume III, tab. IVb) and Breynius (1732, tab. V, fig. 2b). But the table V, figure 2 in Breynius (1732) illustrates a smooth longiconic endocerid, and figure $\mathrm{IVb}$ in Knorr \& Walch (1768-1774, Volume III) an indeterminable fragment of a siphuncle. Because a type specimen was previously designated neither originally nor subsequently, the name " $O$. vaginatus Schlotheim, 1820 " cannot be used.

The first illustration of a species named "O. vaginatus Schlotheim" appears to be published in Buch (1841, p. 592, pl. 33, fig. 11), which was later synonymised with Cyclendoceras buchi Lesnikowa, 1949. According to the opinion of Balashov (1968) Cyclendoceras buchi belongs to Lobocyclendoceras and "Endoceras vaginatum Schloth" in Eichwald (1860, pp. 1243-1245, pl. 48, figs 1a-e) is identical with Paleocyclendoceras eichwaldi Balashov, 1968. Dzik (1984) finally subsumed these species under "Anthoceras vaginatum (Schlotheim, 1820)". Additional annulated endocerids of the Kunda stage limestones that were synonymised with "A. vaginatum" by Dzik (1984) are Paracyclendo- 
ceras cancellatum (Eichwald, 1860), Paracyclendoceras compressum Balashov, 1968, Protocycloceras balticum Balashov, 1968, Protocycloceras iruense Balashov, 1968, and Lobocyclendoceras kundense Balashov, 1968. The different taxa are mainly distinguished by their shape of the endosiphuncular deposits.

The revision of this common and relatively variable annulated endocerids, which would include a detailed analysis of the shape of the endosiphuncular structures is not within the scope of this paper. Herein, I refer to it provisionally as Anthoceras buchi, because "O. vaginatum Schlotheim, 1820" is indeterminate and Cyclendoceras buchi Lesnikowa, 1949 is the first available name representing this group of annulated and striated endocerids of the Kunda Regional Stage limestones and its equivalents in Baltoscandia. The specimens are classified within Anthoceras, because it is an annulated endocerid with subholochoanitic septal necks (see e.g. Balashov 1968, pl. 20, fig. 2g, pl. 23, fig. 3b).

\section{Methods}

I investigated all specimens of Anthoceras buchi in the collections of the NRM, counted, classified and measured the conch breakages. The specimens observed in the MB and TUG were not included in the statistical analyses. The depth of the breakages were measured with calipers. The depth was measured as the distance of the deepest point of the scar posteriorly from the anterior margin of the scar. The frequency of different repair scar depth classes was calculated. The individual conch diameter at each repair scar position was measured and the frequency distribution of repair scars in classes of conch diameter was calculated. The measurements were directly taken from the specimens with a precision of $+/-1 \mathrm{~mm}$.

The frequency of repaired injuries was calculated in different ways (Table 1), following Kowalewski (2002), Alexander \& Dietl (2003), and Ebbestad \& Stott (2008). Three types of abundance ratio are the result of the calculations: 1) the ratio of specimens with at least one, or multiple injuries against the total number of specimens, 2) the ratio of total number of scars against the total number of specimens (scars per shell method, Ebbestad \& Stott 2008), and 3) the ratio of specimens with multiple repair scar against total number of specimens (see Ebbestad \& Stott (2008) for further references of this method).
The position of the repair scars around the circumference was determined by measuring the angle departing from the venter, where ventral is $0^{\circ}$, dorsal $180^{\circ}$, the right flank viewed in direction of growth (adapical view) is $90^{\circ}$, the left flank $270^{\circ}$. The conch was separated into 18 zones with $20^{\circ}$ degree widths $\left(0-20^{\circ}, 20-40^{\circ}, 40-60^{\circ}\right.$, etc). The frequency of injuries at each zone was calculated. The preservational potential of the individual zones was estimated as a function of missing conch parts in the available specimens against the total number of measured specimens. This was realized by measuring the range of angles departing from the venter of the preserved conch parts in each specimen. The percentage of the ranges with conch parts preserved against the total number of specimens is the preservational potential. A zone of the conch was considered as "not preserved" when the shell in more than half of the length of the specimen was abraded in this zone.

The frequency distribution of injuries at individual ranges of positions then was corrected by the probabililty of the parts of the conch of not being preserved.

\section{Results}

\section{Size and shape of repair scars}

All the documented injuries in Anthoceras buchi in the collections of the NRM and MB are original breakages from the aperture at different growth stages. Because nautiloids have accretionary shell growth, the non-lethal breakages were healed and are preserved as irregularities or scars in subsequent shell growth.

The regeneration of the fractured shell of Nautilus was described in detail by Keupp (1998). In Nautilus the repairing shell is substructed forming a wedge under the margin of the broken shell. The repair technique, which involves an intermittent withdrawal of the peristomal mantle margin, is probably common in most molluscs with accretionary growth. The resulting repair pattern, with sometimes slightly outward bulged conch portions and irregular sculpture pattern was named "forma substructa" in a terminology of ammonoid pathological conch forms by Hölder (1973) (see also Hengsbach (1996) for a review of the "forma types"). Without exception, the documented injuries in

Table 1. Abundances and frequency of injuries in Anthoceras buchi (Lesnikowa, 1949), Kunda Regional Stage, middle Darriwilian, Sweden. All specimens are in the collection of the NRM. ${ }^{\circ}$ calculated as ratio of the total number of repair scars against the total number of specimens, ${ }^{*}$ calculated as ratio of specimens with multiple repair scars against the total number of specimens with breakages, $\wedge$ calculated as mean depth of breakage against the mean diameter of conch at the position of injury (at the interimistic conch margin).

\begin{tabular}{|c|c|c|c|c|c|c|}
\hline & Specimens total & $\begin{array}{l}\text { with scars } \\
\text { (percentage of } \\
\text { specimen with at } \\
\text { least one injury) }\end{array}$ & $\begin{array}{l}\text { with multiple scars } \\
\text { (percentage of } \\
\text { specimen with } \\
\text { multiple scars) }\end{array}$ & scars per shell ${ }^{\circ}$ & $\begin{array}{l}\text { multiple versus } \\
\text { injured* }\end{array}$ & 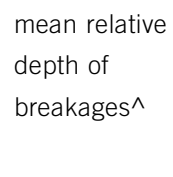 \\
\hline Dalarna & 52 & $20(38 \%)$ & $10(19 \%)$ & 0.75 (39 scars) & 0.5 & 0.15 \\
\hline Västergötland & 19 & $3(16 \%)$ & $2(11 \%)$ & 0.47 (9 scars) & 0.67 & 0.27 \\
\hline Östergötland & 120 & $26(22 \%)$ & $7(6 \%)$ & 0.3 (36 scars) & 0.27 & 0.1 \\
\hline Öland & 45 & $19(42 \%)$ & $6(13 \%)$ & 0.71 (32 scars) & 0.32 & 0.12 \\
\hline Total & 236 & $68(29 \%)$ & $25(11 \%)$ & 0.49 (129 scars) & 0.36 & 0.14 \\
\hline
\end{tabular}


Anthoceras buchi represent shell malformations of the type "forma substructa".

Most of the breakages are pit-like (= typus parvus, Kröger 2000) with depths less than $2 \mathrm{~mm}$ from the interimistic apertural conch margin $\left(n=61\right.$ of $n_{\text {ss-total }}$ $=121,50 \%$; with $\mathrm{n}_{\text {ss-total }}=$ subsample of classified scars within total sample number of 129 scars). Small u-shape breakages (=typus stupidus, Kröger 2000) with depths of $2-5 \mathrm{~mm}$ are also common $(\mathrm{n}=14,=12 \%)$ (Fig. 2). The small pit-like and u-shaped scars can be classified as "divots" sensu Alexander \& Dietl (2003). Often $(n=25,=19 \%)$ multiple small breakages (= "scallops" sensu Alexander \& Dietl 2003)
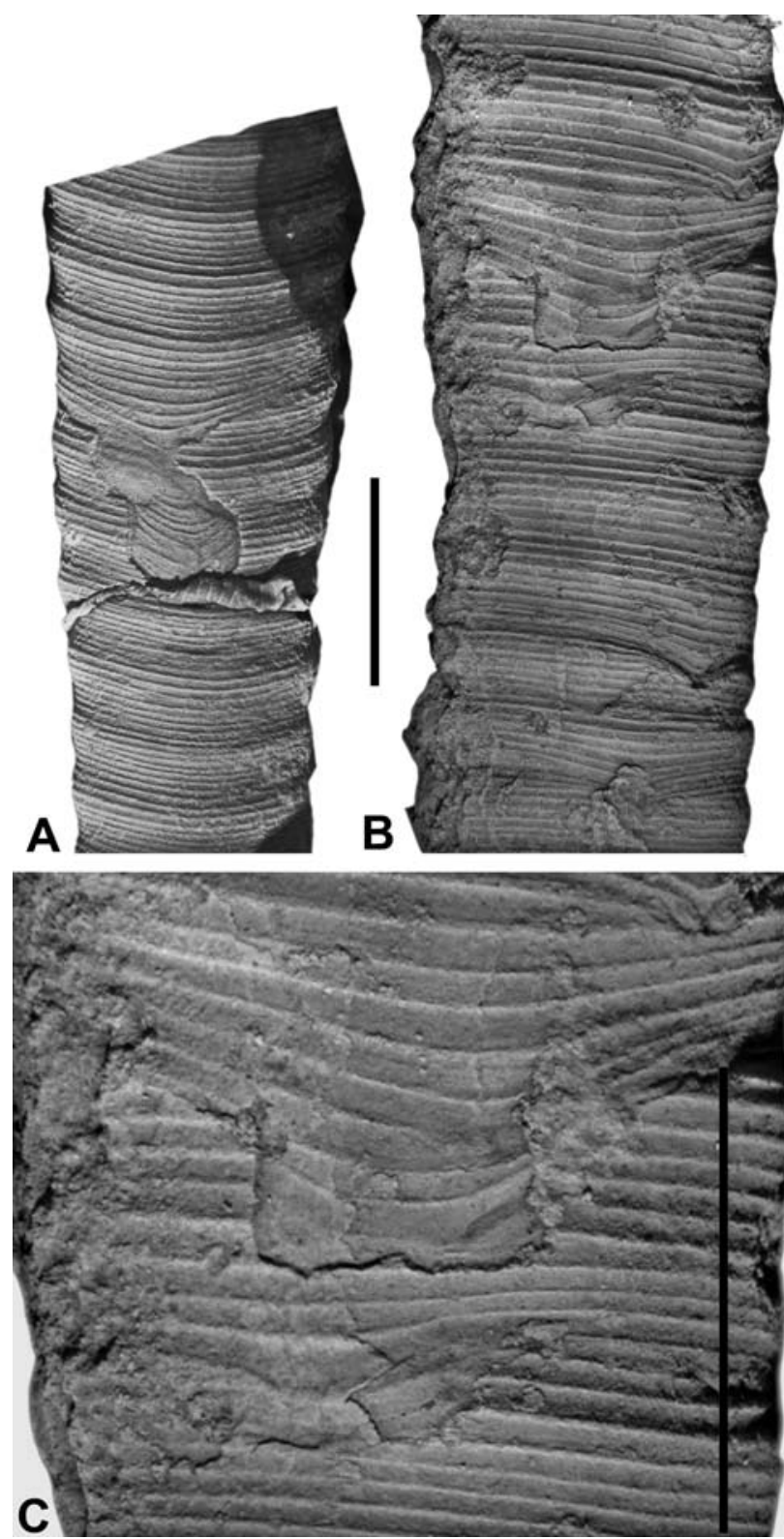

Figure 2. Anthoceras buchi (Lesnikowa, 1949), Kunda Regional Stage, with u-shaped or slit-like repaired shell breakages. A. NRM Mo $167604 \mathrm{a}-\mathrm{b}$, from Mölltorp, Billingen, Sweden with narrow slit-like repaired breakage with distal widening; B-C. NRM Mo 8948, from Digerberget, Dalarna, Sweden. Scale bar $10 \mathrm{~mm}$. occur along an interimistic apertural conch margin (Fig. 3B). The largest breakages are often slit-like (Fig. 2), with depths significantly larger than widths (= "embayments" sensu Alexander \& Dietl 2003). Remarkably the slit-like breakages in some cases show distal widenings (Fig. 2A). Rarely, deep breakages occur that comprise large parts of the apertural margin (Fig. 4). Only in one case (Fig. 2C), the breakage is deep and v-shaped (= typus acutus, Kröger 2000; = "divot" sensu Alexander \& Dietl 2003). The greatest measured depth of a breakage in the material of Anthoceras buchi in all collections investigated is $27 \mathrm{~mm}$ (specimen NRM Mo 167603 from Ljung, Östergotland, Sweden). It occurs at a conch diameter of $29 \mathrm{~mm}$.

The average depth of breakages in specimens of different size classes reveals a specific pattern: In specimens with injuries at conch diameters of $25-30 \mathrm{~mm}$ the breakages are significantly more severe. The deepest breakages occur in conchs of these size classes and the breakages are also in the average deeper at conch regions with diameters of 25-35 mm (Fig. 5).

\section{Position and abundance of injuries}

Nearly one third (29\%, Table 1) of all specimens of Anthoceras buchi in the collection of the NRM have shell injuries. The relative abundance of healed shell fractures is very similar in the specimens from Dalarna, Östergotland, and Öland. In these specimens, multiple injuries are also very common. Repair scars are less common in specimens from Västergötland. Multiple repair scars are more common in conch portions with smaller diameter. The relative number of multiple scars at different size classes is highest in conch fragments with diameter $15-20 \mathrm{~mm}$. Multiple scars do not occur in fragments with diameter $>30 \mathrm{~mm}$ (Fig. 6).

The relative abundance of repair scars at individual positions around the circumference of the conch before and after correction against preservation probability of the related conch parts is uneven. Generally repair scars are slightly more common on the left side of the conch. The ratio of scars at the left against scars at the right is $1.26(n=120), 56 \%$ of the scars occur at the left side. Because the left side has a significantly higher potential not to be preserved and eroded or dissolved (Fig. 7A) the left/right discrepancy of the breakage frequency nearly disappears after correction against the preservation potential $(51 \%$ of the breakages occur at the left side after correction). The causes of this preferential right side preservation of the shell are unknown.

Small breakages which penetrated less than $3 \mathrm{~mm}$ posteriorly beneath the anterior margin of the scar show conspicuous peaks at positions $20-40^{\circ}, 100-120^{\circ}$, and $220-240^{\circ}$ after correction against preservation potential (Fig. 7B). The larger breakages with depths of more than $5 \mathrm{~mm}$ are concentrated at the ventral half of the conch with frequency maxima at $20-40^{\circ}, 60-80^{\circ}$, and $300-320^{\circ}$ (Fig. 8). 

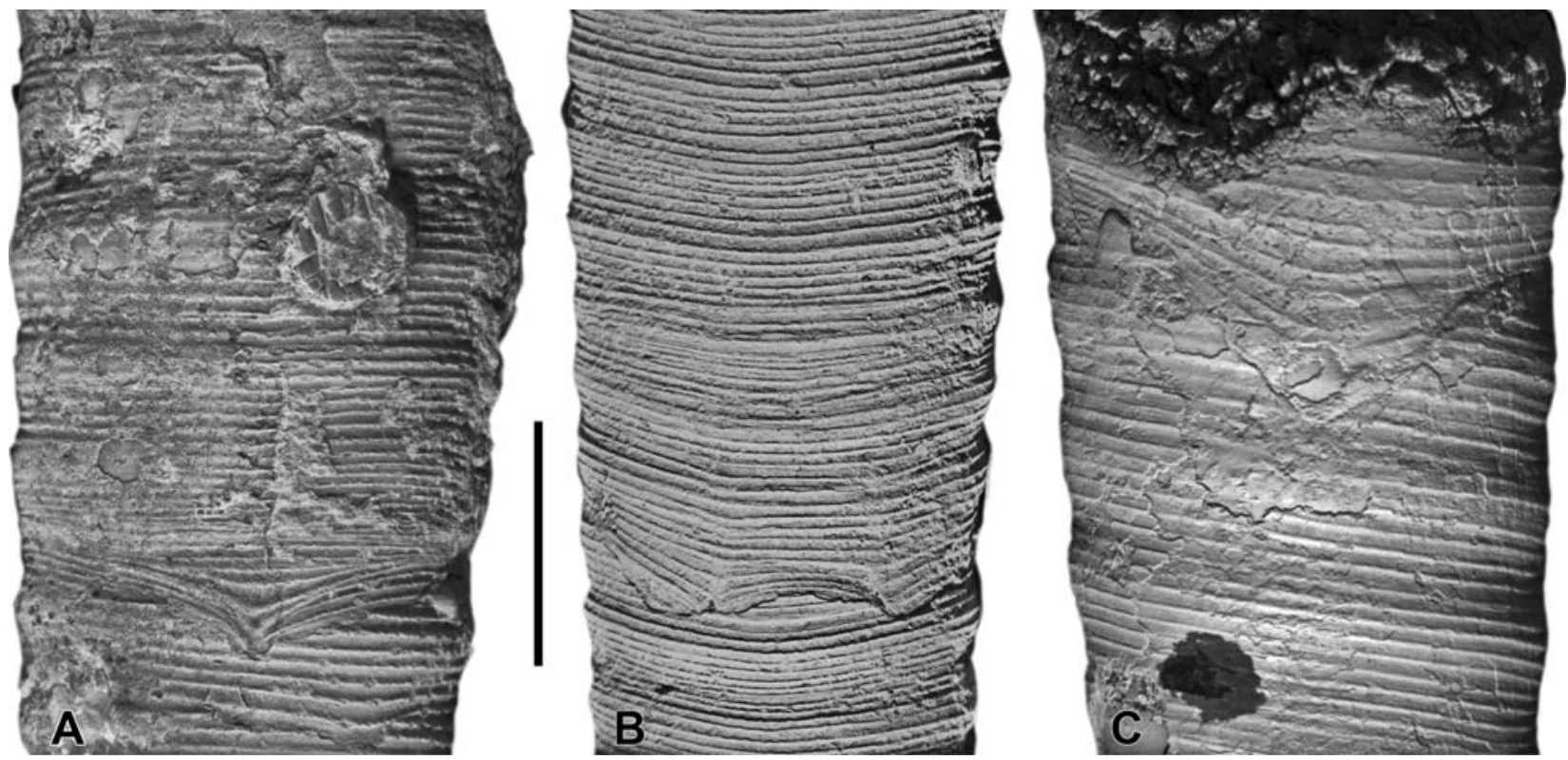

Figure 3. Small or v-shaped repaired shell breakages in Anthoceras buchi (Lesnikowa, 1949), Kunda Regional Stage. A. NRM Mo 14636, Norre Udde, Öland, Sweden with pit-like repaired breakage; B. NRM Mo 167604 a-b, from Mölltorp, Billingen, Sweden, same specimen as in Figure 2A, with wide irregular shallow repair scar; C. NRM Mo Mo 167602 a-c, from Sjurberg, Dalarna, Sweden with relatively deep v-shaped breakage. Scale bar $10 \mathrm{~mm}$.

\section{Interpretation}

\section{Conch size matters}

Because it was affected by the several taphonomical and ecological variables the interpretation of shell repair frequency is not trivial. The probability of the individual of getting attacked during its life time, the severity of attacks, the type of attacks (the rate of unsuccessful attacks), and the resilience of the prey are important factors to be considered. The shell size, and the probability of different shell portions to be preserved affect the abundance of repairs.

In the fossil material, the severity of attacks can be evaluated based solely on the preserved repairs after unsuccessful attacks. The mean depths posteriorly from the anterior margin of the scars and the rate of multiple traces can be considered as good proxies of the severity of the average attack (and as a side note: potentially as evidence for a size limitation of the predators "tool"). A relatively high number of deep and large scars can be interpreted as concentration of severe attacks. Con-
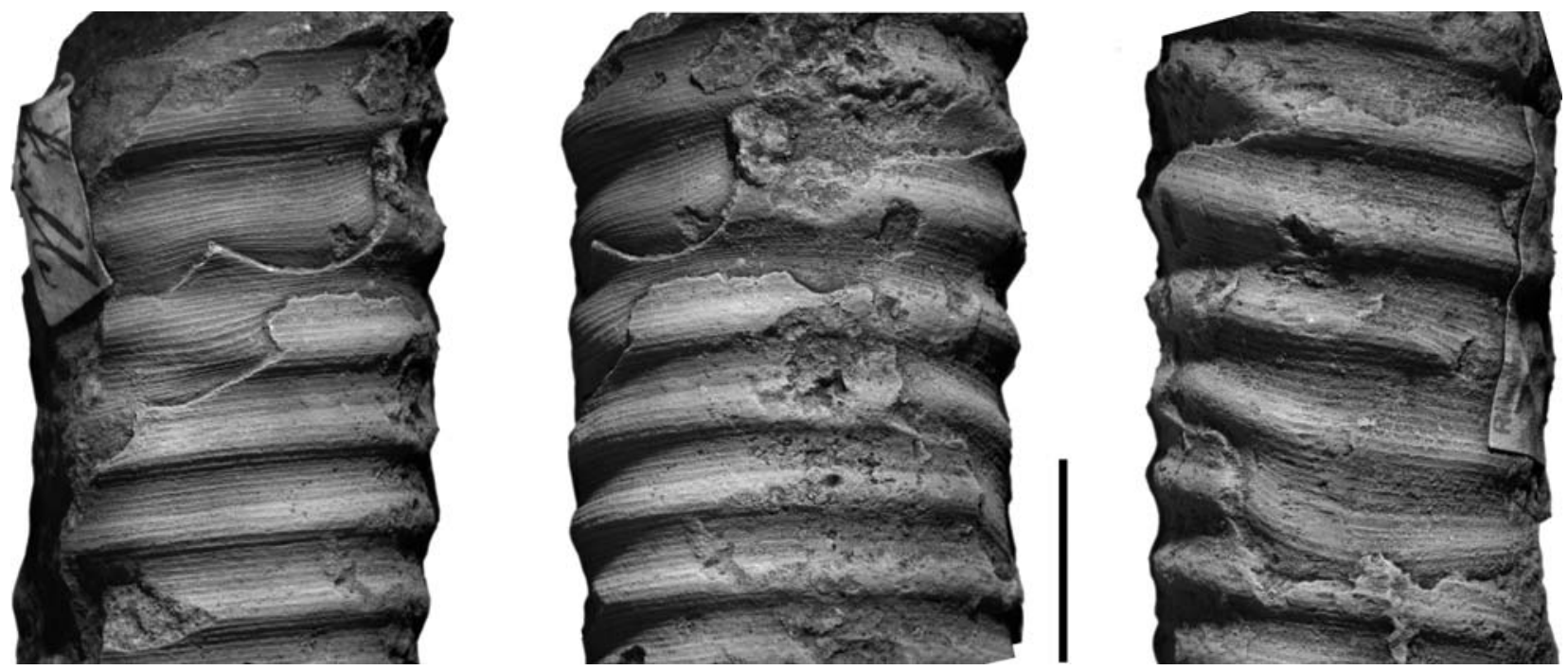

Figure 4. Anthoceras buchi (Lesnikowa, 1949), NRM Mo 10005, labelled "Red Orthoceras Limestone", Kunda Regional Stage, from Kinnekulle, Västergotland, Sweden, with multiple large and deep repaired shell breakages comprising the entire circumference. From left to right: lateral view from the left side, dorsal view, lateral view from the right side. Scale bar $10 \mathrm{~mm}$. 


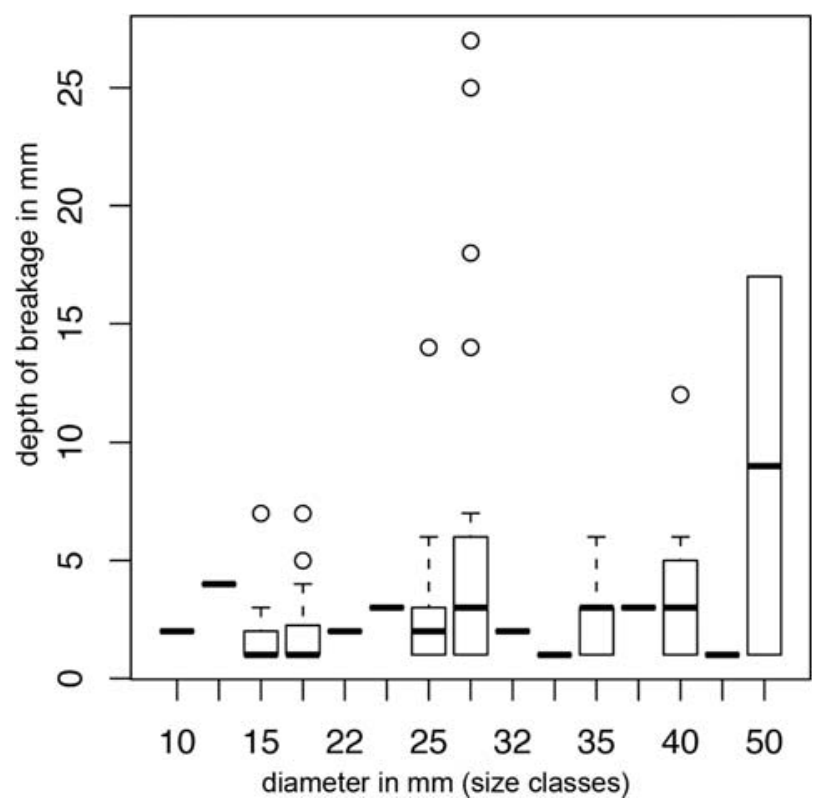

Figure 5. Box plot of depth of repair scars in different size classes of Anthoceras buchi (Lesnikowa, 1949), $n=129$, circles $=$ maximum values, bold bars mean values, empty box $95 \%$ confidence interval, dotted lines $65 \%$ confidence interval. Note the maximum values at conch diameters of $25-$ $30 \mathrm{~mm}$. The large depths in the size class $>45 \mathrm{~mm}$ is based on two values only.

trarily, a high rate of multiple traces in individual shells indicates abundant interaction of low severity.

Small specimens of Anthoceras buchi often contain small breakages and multiple breakages, while specimens with diameter of $25-30 \mathrm{~mm}$ contain the deepest

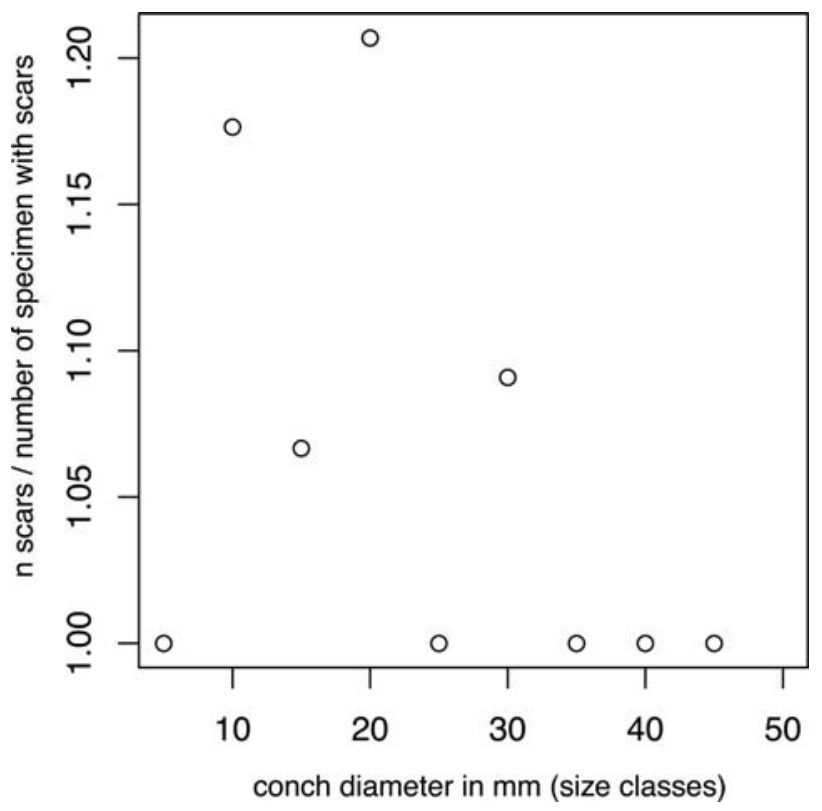

Figure 6. Plot of relative number of multiple injuries in conchs of different size classes. Note the decreasing trend of multiple injuries with increasing diameter of the conch.

breakages and also often contain multiple breakages. Larger specimens rarely contain breakages at all. The probability of getting injured is highest at diameters of $15-20 \mathrm{~mm}$. This pattern can be interpreted as evidence for a size limitation of the predator: large specimen with conch diameters exceeding $30 \mathrm{~mm}$ had a considerably lower risk to get injured, and the preserved injuries were less severe. This implies that the large endocerid
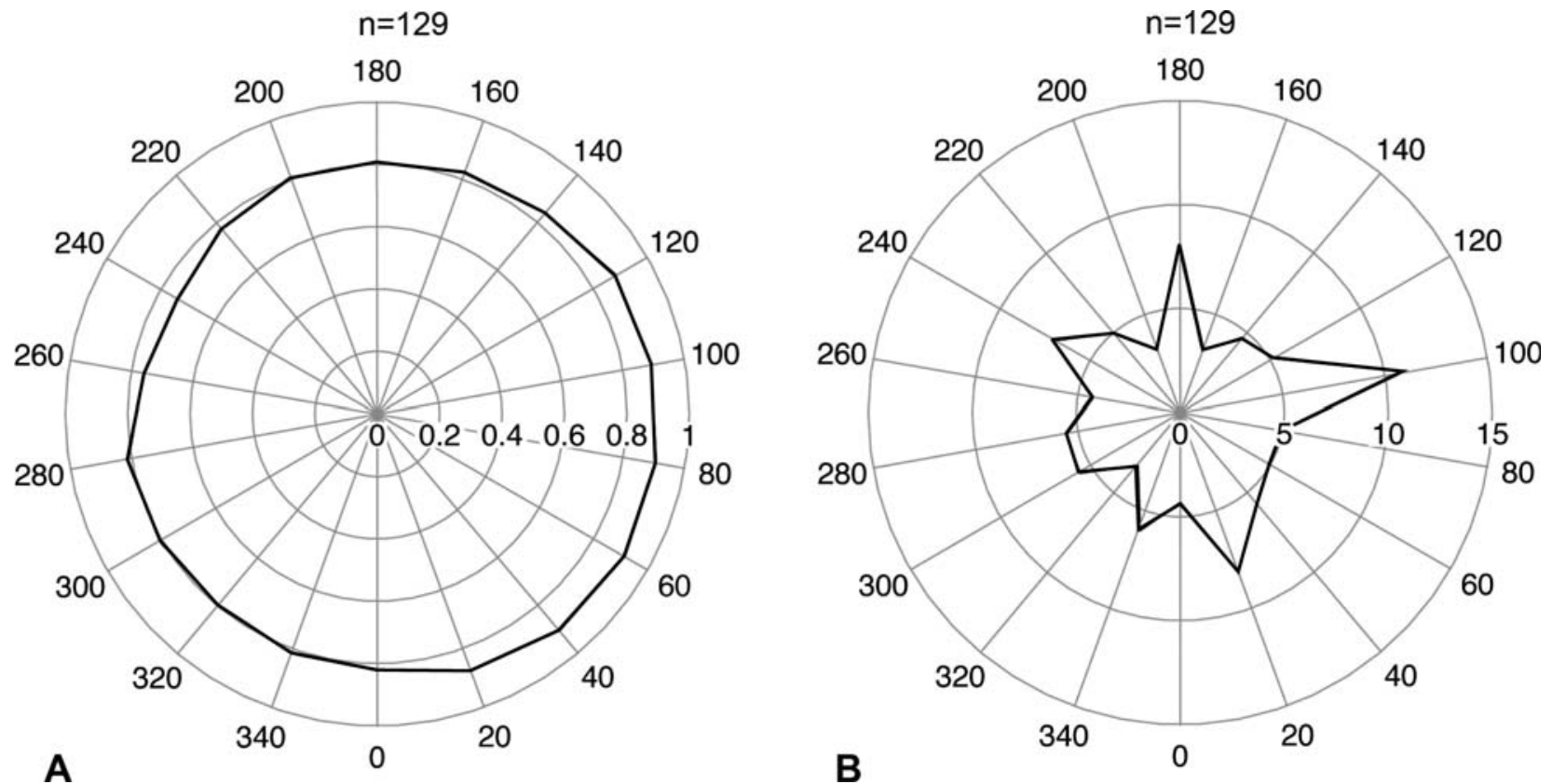

Figure 7. Frequency distribution of healed injuries around circumference of aperture in degrees, $0^{\circ}=$ ventral, $180^{\circ}=$ dorsal, in adapical view. A. Preservational potential of the conch in different sections. Conch sections with lowest probability are the least common preserved with shell in the documented specimen. Note the left/right discrepancy. B. Frequency distribution of all documented injuries around circumference, in percentage. 


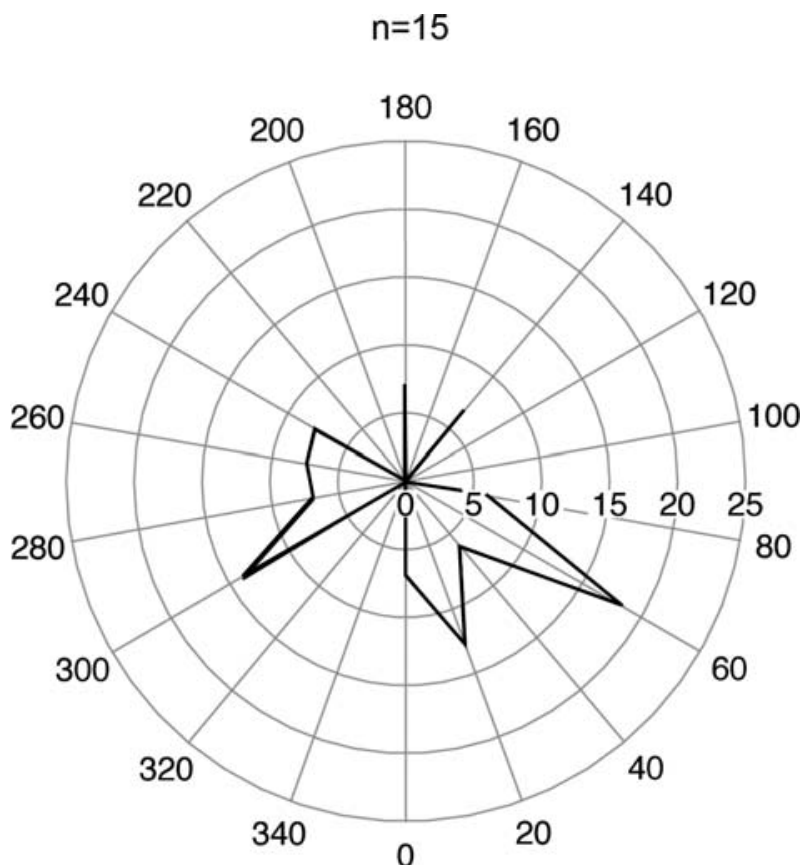

Figure 8. Frequency distribution of large healed injuries (breakages penetrated more than $5 \mathrm{~mm}$ posteriorly from anterior margin of scar) around circumference of aperture in degrees, $0^{\circ}=$ ventral, $180^{\circ}=$ dorsal, in adapical view. Note the concentration at the ventral parts of the aperture.

conchs reached a functional size refuge where they became big enough so that very few injuries occurred (see e.g. Leighton (2002) and Harper et al. (2009) for the discussion of this specific aspect of predator/prey relationship).

\section{Conch position matters}

Repair scars nearly have the same frequency on both sides of the conch when corrected for the preservation potential of the respective conch parts (left/right: 51/ $49 \%$ ). Nonetheless, the frequency distribution of injuries around the circumference of the interimistic aperture is not even (Figs 6-7). It is difficult to compare these frequency pattern with patterns known from $\mathrm{Nau}$ tilus or ammonoids, because the coiling of the shell in these cephalopods by itself prevents dorsal breakages. But in ammonoids a clear concentration of repair scars at ventral shell parts is apparent (Kröger 2002; Klompmaker et al. 2009). This is not the case for small repair scars in endocerid shells. Thus, endocerids were attacked not only from the bottom-directed side but also from the water column, from swimming predators.

Figure 9. Anthoceras buchi (Lesnikowa, 1949), MB.C. 21996, from erratic boulder, Grey Orthoceratite Limestone, Kunda Regional Stage, Nienhagen, Mecklenburg, Germany, with irregularly mottled colour marks. Colour marks highlighted in the right figure. Scale bar $10 \mathrm{~mm}$.
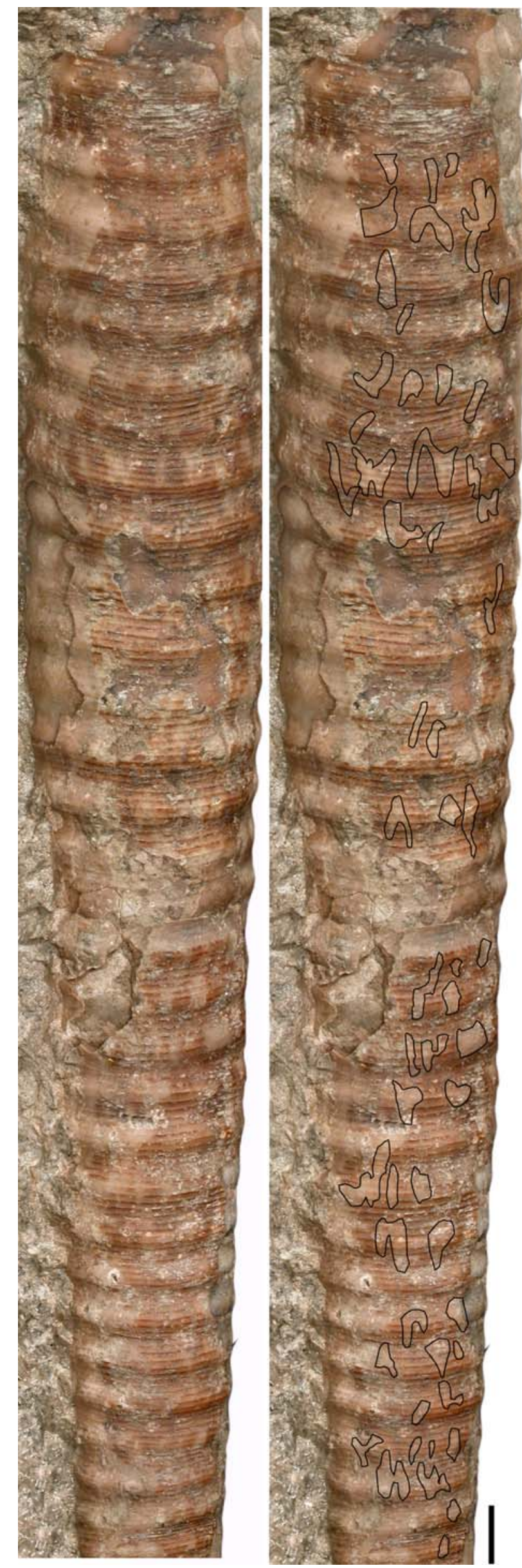
The colour pattern of Anthoceras buchi is known from a specimen from the erratics of northern Germany (Fig. 9). The preserved conch part displays an irregular network of dark broad bands forming irregular light deltoids or a mottled pattern. This pattern resembles irregular shadows of elongate objects like e.g. Posidonialike water plants at the ground and probably indicates an habitat in seaweed fields or a bottom with small irregular ripples. The specimen gives no evidence of a dorsal/ventral differentiation in colour pattern. No correlation of a shell side with the colour pattern and injury frequency can be detected.

The aperture of Anthoceras buchi is nearly directly transverse (Fig. 1). A shallow broad ventral sinus is developed and at the lateral sides the aperture runs slightly oblique in apical direction toward the venter. The ventral emargination may be interpreted as a hyponomic sinus. The concentration of large repair scars at the ventral side is thus probably a result of the relatively low protection potential of this part of the aperture when assuming a dorsal hood. However, no direct correlation between apertural shape and injury frequency can be detected.

Because the repair scar frequency appears unrelated to apertural shape and colour pattern, the concentration of repaired scars at specific ranges along the circumference may reflect specifically unprotected areas, which were more susceptible for bites. A dorsal hood may have played an important role for protection.

Noteworthy, only a single injury of the apertural mantle epithelium is known from Anthoceras buchi (TUG 860-1640, from Kunda regional stage, Nehatu, northern Estonia). This type of injury forms narrow lateral furrows or scars in the shell and can reach considerable depths. Hölder (1956) termed this type of injuries forma verticata (Hengsbach 1996; = "tracked clefts" sensu Alexander \& Dietl 2003). In Jurassic ammonoids healed injuries of the type forma verticata occur sometimes in up to $40 \%$ of the conchs (Kröger 2002) and are generally more common. In ammonoids a correlation of the relative frequency of injuries of the peristomal mantle epithelia and the frequency of multiple injuries is obvious. Additionally, injuries of the peristomal mantle epithelia and multiple injuries are often more common in ammonoids with long body chambers and a high ability of withdrawing the body into the shell. In Anthoceras buchi the body chamber is very short, suggesting only little potential for withdrawing of the soft body into the shell. The scarcity of injuries of the peristomal mantle epithelia supports the interpretation of a high vulnerability of the soft body against predatory attacks in endocerids. The high rate of multiple injuries (36\% in Anthoceras buchi against a maximum of $20 \%$ in Jurassic ammonoids, Kröger 2002) and the occurrence of severe slit-like repair scars contradict this impression. By contrast, a high rate of repaired scars does not necessarily indicate a low rate of successful attacks that affect the peristomal mantle epithelia. It appears quite likely that the soft body of
Anthoceras buchi was much more vulnerable against attacks compared with ammonoids. The speculative protective function of the aptycha of some Jurassic ammonoids (Engeser \& Keupp 2002) may explain the discrepancy.

\section{Possible predators}

The shape of the scars are partly a result of specific modes of attacks (Schäfer 1954). Additionally, the conch form and ornamentation plays an important role for the resulting breakage pattern caused by an attack (Stridsberg 1988; Kröger 2002). Transverse annuli, and constrictions which are common in Anthoceras buchi have the potential to redirect the shear power during a bite and eventually spatially constrain fractures and fissures. Fractures parallel to the aperture and distal widenings (Fig. 2A) at the distal rim of the deepest breakages thus can be interpreted as a result of the transverse ornamentation in Anthoceras buchi. Similar distal widenings of slit-like breakages are known from annulate ammonoids (e.g. Isakar \& Ebbestad 2000, figs 4, 6g; Kröger 2000, figs 17-18, 32, 33a). The rarity of injuries of the forma verticata type may indicate that the conch breaking device of the predators were not very sharp or acute, and therefore unable to injure a flexible epithelium. The occasional deep, slit-like breakages can only be explained by predators that were able to fix their prey and to peel the shell in a controlled attack. The concentration of these deep breakages at the ventral part of the prey further indicate 1) either some control over the position of the peeling or 2) a less protected aperture or 3) a combination of both. Similar slit-like breakages are known from modern crustaceans with chelae. Chelae of $10 \mathrm{~mm}$ length which could potentially have inflicted larger slit-like breakages preserved in Anthoceras buchi are not known in any Middle Ordovician arthropod (see also Kröger 2000; Brett \& Walker 2002). Cephalopods with massive beaks and the potential to fix their prey with arms or tentacles are other potential predators. Since not a single pre-Carboniferous unequivocal non-ammonoid cephalopod beak has been found so far, the actual originators of the large slit-like breakages cannot be identified yet (see also Brett \& Walker 2002; Kröger 2004).

\section{Conclusion}

The high frequency of repaired scars in specimens of Anthoceras buchi is striking, with $29 \%$ of the conchs being injured. In average 0.49 repaired scars occur per conch. These frequencies are comparable only with repair scars documented in the Late Ordovician Laurentian gastropod Trochonemella sp. (Ebbestad \& Stott 2008 ) of which $36 \%$ are injured. In Trochonemella sp. the number of scars per shell is 0.46 . Ebbestad \& Stott (2008) pointed out that these percentages are in the 
range of injury frequencies known from Mesozoic molluscs. They are exceptional in the Ordovician and probably indicate high exposure to durophagous predators. The annulated and constricted conch of Anthoceras ex gr. buchi can be interpreted as an adaption against conch breaking predators (Vermeij 1977; Brett \& Walker 2002; Kröger 2002) and is additional evidence for a high exposure to durophagous predators.

In contrast to Trochonemella sp., most injuries in $\mathrm{An}$ thoceras buchi did not occur in the larger size classes. Most injuries, as well as the most severe cases occur in medium sized, premature conchs. In large, and mature specimens healed injuries where not only less severe but multiple repair scars are less common (Figs 5-6). This is interpreted as indication for a size limitation of the unknown predator. The large size of endocerids, thus can be interpreted as a size refuge against predator.

The position of the repair scars (often dorsal), their shape (often slit-like), and their depth (sometimes several centimetres behind the anterior margin of the scar) suggest that other cephalopods, most probably other endocerids or even Anthoceras ex gr. buchi itself were the originators of these injuries. Endocerids were the largest molluscs (Teichert \& Kummel 1960) and the largest potential durophagous predators in the Middle and Late Ordovician (see discussion in Frey 1995; Kröger 2004).

Kröger \& Landing (2010) detected a trend of increasing body size, conch strength, and mobility in cephalopods of the Early Ordovician platform carbonates of eastern Laurentia. They interpreted the evolutionary trends as a possible result of increasing competition and an escalation among predators. Endocerids are a major component and among the largest taxa in these Laurentian carbonates. In endocerids, the Ordovician trend of size increase was the strongest.

The size limitation of the predators of Anthoceras ex gr. buchi and as a conseqence a size refuge of the prey may have been an important factor in the excessive size evolution of endocerids in general and are another argument for predatory escalation as driving evolutionary factor among Ordovician cephalopods. However, a rigorous quantitative testing of this hypothesis is needed for further evaluation of the driving evolutionary factors of endocerids.

\section{Acknowledgements}

This investigation is the result of several visits to the NRM and to the TUG. During these visits I was financially supported by the SYNTHESYS Grant SE-TAF 5040 and by the Humboldt Foundation. I am grateful to Harry Mutvei (Stockholm, Sweden), Jan Ove Ebbestad (Uppsala, Sweden), and Mare Isakar (Tartu, Estonia) who supported me during my work in the collections and in the field and who provided me with additional information about the material. Many thanks to Jens Koppka (Pruntrut, Switzerland), who donated me the specimen with colour marks. This is a contribution to the IGCP Project $\mathrm{N}^{\circ} 503$ "Ordovician Palaeogeography and Palaeoclimate". The comments of the three reviewers J. O. R. Ebbestad (Uppsala, Sweden), C. Klug (Zürich, Switzerland), and M. Kowalewski (Blacksburg, VA, USA) were very helpful.

\section{References}

Alexander, R. R. \& Dietl, G. P. 2003. The fossil record of shellbreaking predation on marine bivalves and gastropods. In Kelley, P. H., Kowalewski, H. \& Hansen, T. A. (eds). Predator-prey interactions in the fossil record. Kluwer Academic/Plenum Publishers, New York: pp. 141-176.

Balashov, E. G. 1968. Endoceratoidei ordovika SSSR. Isdatelstvo Leningradskogo Universiteta, Leningrad.

Brett, C. E. \& Walker, S. E. 2002. Predators and predation in Paleozoic marine environments. - Paleontological Society Papers 8: 93-118.

Breynius, J. P. 1732. Dissertatio physica de polythalamiis, nova testaceorum classe, cui quaedam praemittuntur de methodo testacea in classes et genera distribuendi. Huic adiicitur commentatiuncula belemnitis prussicis; tandemque schediasma de echinis methodice disponendis. Cornelium A Beughem, Gedani.

Buch, L. von. 1841. Beiträge zur Bestimmung der Gebirgsformationen in Russland. - Archiv für Mineralogie, Geognosie, Bergbau und Hüttenkunde 15: 3-128.

Dzik, J. 1984. Phylogeny of the Nautiloidea. - Palaeontologia Polonica 45: 3-203.

Ebbestad, J. O. R. 1998. Multiple attempted predation in the Middle Ordovician gastropod Bucania gracillima. - GFF 120 (1): 27-33.

Ebbestad, J. O. R. \& Peel, J. S. 1997. Attempted predation and shell repair in Middle and Upper Ordovician gastropods from Sweden. - Journal of Paleontology 71: 1007-1019.

Ebbestad, J. O. R. \& Stott, C. A. 2008. Failed predation in Late Ordovician gastropods from Manitoulin Island, Ontario, Canada. - Canadian Journal of Earth Sciences 45: 231-241.

Eichwald, E. de. 1860. Lethaea Rossica ou Paléontologie de la Russie. Schweizerbart, Stuttgart.

Engeser, T. \& Keupp, H. 2002. Phylogeny of the aptychi-possessing Neoammonoidea (Aptychophora nov., Cephalopoda). - Lethaia 34: 79-96.

Frey, R. C. 1995. Middle and Upper Ordovician Cephalopods of the Cincinnati Region of Kentucky, Indiana, and Ohio. - United States Geological Survey Professional Paper 1066 P: 1-119.

Frisk, Å. M. \& Ebbestad, J. O. R. 2007. Paragastropoda, Tergomya and Gastropoda (Mollusca) from the Upper Ordovician Dalby Limestone, Sweden. - GFF 129 (2): 83-99.

Harper, E., Peck, L. \& Hendry, K. 2009. Patterns of shell repair in articulate brachiopods indicate size constitutes a refuge from predation. - Marine Biology 156 (10): 1993-2000.

Hengsbach, R. 1996. Ammonoid pathology. In Landman, N. H., Tanabe, K. \& Davis, R. A. (eds). Ammonoid Paleobiology. Plenum Press, New York: pp. 581-605.

Hölder, H. 1956. Über Anomalien an jurassischen Ammoniten. Paläontologische Zeitschrift 30: 95-107.

Hölder, H. 1973. Miscelleana cephalopodica. - Münsterländer Forschungshefte Geologie Paläontologie 29: 36-76.

Isakar, M. \& Ebbestad, J. O. R. 2000. Bucania (Gastropoda) from the Ordovician of Estonia. - Paläontologische Zeitschrift 74: 51-68.

Ivantsov, A. J. 2003. Ordovician Trilobites of the Subfamily Asaphinae, of the Ladoga Glint. - Paleontological Journal 37 (Supplement 3): 229-336.

Keupp, H. 1998. Mundsaumverletzungen bei Pleuroceras (Ammonoidea). - Fossilien 1998 (1): 37-42.

Klompmaker, A. A., Waljaarden, N. A. \& Fraaije, R. H. B. 2009. Ventral bite marks in Mesozoic ammonoids. - Palaeogeography, Palaeoclimatology, Palaeoecology 280: 245-257. 
Knorr, W. \& Walch, J. E. I. 1768-1774. Die Naturgeschichte der Versteinerungen: zur Erläuterung der Knorrischen Sammlung von Merkwürdigkeiten der Natur herausgegeben/von Johann Ernst Immanuel Walch, Hochfürstl. Sachsen-Weimarischen und Eisenachischen Hofrath, wie auch der Beredsamkeit und Dichtkunst ordentlichen öffentlichen Lehrer auf der Universität zu Jena. Volume I-III. Felsecker, Paul Jonathan, Nürnberg.

Kowalewski, M. 2002. The fossil record of predation: An overview of analythical methods. - Paleontological Society Papers 8: 3-42.

Kröger, B. 2000. Schalenverletzungen an jurassischen Ammoniten ihre paläobiologische und paläoökologische Aussagefähigkeit. Berliner Geowissenschaftliche Abhandlungen, Reihe E 33: 1-97.

Kröger, B. 2002. Antipredatory traits of the ammonoid shell - Indications from Jurassic ammonoids with sublethal injuries. - Paläontologische Zeitschrift 76 (2): 223-234.

Kröger, B. \& Landing, E. 2010. Early Ordovician community evolution with eustatic sea level change through the middle Beekmantown Group, northeast Laurentia. - Palaeogeography, Palaeoclimatology, Palaeoecology 294: 174-188.

Leighton, L. R. 2002. Inferring predation intensity in the marine fossil record. - Paleobiology 28 (3): 328-342.

Lesnikowa, A. F. 1949. Ortryad nautiloidei. - Atlas rukovodjashikh form iskopaemykh faun SSSR 2: 253-261.

Lindström, A. \& Peel, J. S. 2005. Repaired injuries and shell form in some Palaeozoic pleurotomarioid gastropods. - Acta Palaeontologica Polonica 50: 697-704.
Schäfer, W. 1954. Form und Funktion der Brachyuren Schere. - Abhandlungen der Senckenbergischen Naturforschenden Gesellschaft 489: $1-65$.

Schlotheim, E. F. von. 1813. Beiträge zur Naturgeschichte der Versteinerungen in geognostischer Hinsicht. - Leonards Taschenbuch 7 (1): $3-134$.

Schlotheim, E. F. von. 1820. Die Petrefactenkunde auf dem jetzigen Standpunkte durch die Beschreibung seiner Sammlung versteinerter und fossiler Überreste des Thier- und Pflanzenreichs der Vorwelt erläutert. Becker'sche Buchhandlung, Gotha.

Schmidt, F. 1858. Untersuchungen über die Silurische Formation von Ehstland, Nord-Livland und Ösel. - Archiv für die Naturkunde Liv-, Ehst- und Kurlands, 1. Serie (Mineralogische Wissenschaften, nebst Chemie, Physik und Erdbeschreibung) 2: 1-248.

Stouge, S. 2004. Ordovician siliciclastics and carbonates of Öland. International Symposium on Early Palaeozoic Palaeogeography and Palaeoclimate, 5, Erlanger Geologische Abhandlungen, Sonderband: $91-111$.

Stridsberg, S. 1988. A Silurian cephalopod genus with a reinforced frilled shell. - Palaeontology 31: 651-663.

Teichert, C. \& Kummel, B. 1960. Size of endocerid cephalopods. Breviora 128: 1-7.

Vermeij, G. 1977. The Mesozoic marine revolution. Evidence from snails, predators and grazers. Princeton University Press, Princeton, New Jersey. 